\title{
PREFERENSI USAHA KECIL DAN MIKRO DI PASAR BARU CIKARANG DALAM MEMILIH AKSES PEMBIAYAAN
}

\begin{abstract}
SITI AISYAH 1
Abstract: Preference of Micro and Small Enterprise in Pasar Baru Cikarang In Selecting Financing Access. The aim of this research is to measure the micro and small entreprise preference in Pasar Baru Cikarang in selecting of conventional or shariah financing access with using 100 responden. The Method that used in this research is binary logistic regression and descriptive analysis. There are two result of this research, first, the factor that influence the micro and small enterprise preference are the lower interest/yield, diverse product, financing plafond, and presence a guidance of business development. Second, 37 percent respondent stated that they chose to access financing in Islamic Financial Institutions and 63 percent stated that they chose to access financing in Conventional Financial Institutions. From this result we can conclude that the micro and small medium enterprise in Pasar Baru Cikarang is more preferrable access in conventional financial institution.
\end{abstract}

Keyword: Preference, Financing Access, Binary logistic regression

\begin{abstract}
Abstrak: Preferensi Usaha Kecil dan Mikro di Pasar Baru Cikarang Dalam Memilih Akses Pembiayaan. Tujuan dari penelitian ini adalah untuk mengukur preferensi dari usaha mikro dan kecil dalam mengakses pembiayaan berbasis konvensional atau syariah dengan menggunakan 100 orang responden. Metode yang digunakan dalam penelitian ini adalah regresi logistik binary dan analisis deskriptif. Berdasarkan hasil penelitian, didapat dua kesimpulan. Pertama, bahwa hanya ada satu faktor yang mempengaruhi preferensi usaha kecil dan mikro di Pasar Baru Cikarang dalam memilih akses pembiayaan yaitu Faktor Produk yang meliputi: Bunga/Margin/Bagi Hasil yang rendah, produkyang beragam, jumlah plafond yang sesuai dengan kebutuhan dan terdapatnya bimbingan untuk pengembangan usaha. Kedua, berdasarkan hasil analisis deskriptif, bahwa 37 persen yang memilih akses pembiayaan di Lembaga Keuangan Syariah dan 63 persen yang memilih akses pembiayaan di Lembaga Keuangan Konvensional. Dari hasil tersebut, dapat disimpulkan bahwa Usaha Kecil dan Mikro di Pasar Baru Cikarang lebih berminat atau cenderung memilih akses pembiayaan di Lembaga Keuangan Konvensional.
\end{abstract}

Kata Kunci: Preferensi, Akses Pembiayaan, Regresi Logistic Binary

\footnotetext{
${ }^{1}$ Naskah diterima: 10 Oktober 2013, direvisi: 12 Nopember 2013, disetujui: 20 Nopember 2013 BPRS Harta Insan Karimah, Jl. Ciledug Raya, No. 88 B, Larangan, Tangerang, Banten. Email: siti_aisyahzakaria@yahoo.com.
} 


\section{PENDAHULUAN}

Perbankan dan lembaga pembiayaan merupakan sektor yang paling besar pengaruhnya dalam aktifitas perekonomian masyarakat modern, sebagai lembaga keuangan yang menjadi tempat bagi perusahaan, badan-badan pemerintah, swasta maupun perorangan yang menyimpan dana-dananya melalui kegiatan pembiayaan dan berbagai jasa yang diberikan, bank melayani kebutuhan pembiayaan serta melancarkan mekanisme sistem pembayaran bagi semua sektor perekonomian.

Salah satu bentuk pertanggungjawaban sosial Bank dan lembaga keuangan Syariah adalah memberikan pembiayaan kepada UMKM, mengingat UMKM ini merupakan cerminan dari perekonomian rakyat, karena kelompok ini merupakan kelompok dominan, bahkan mayoritas dalam struktur pelaku usaha di tanah air. Hal ini dapat dilihat dari sumber Bappenas sebagaimana dikutip dalam Amalia (2009), bahwa data Usaha Kecil Mikro pada tahun 2007 adalah sebanyak 41,30 juta unit $(99,85 \%)$, Usaha Menengah 61,05 juta unit (0,14\%), dan Usaha Besar 2,2 juta unit (0,005\%). Hingga tahun 2011, UKM yang tersebar di Indonesia sudah mencapai sekitar 52 juta. Dari jumlah tersebut, dampaknya pada penyerapan tenaga kerja, sumbangan terhadap PDB, nilai ekspor non-migas, dan nilai investasi tidak dapat dianggap kecil. Oleh karena itu, di tengah krisis ekonomi, UMKM memiliki peran penting bagi perekonomian suatu negara.

Ironisnya, meski keberadaan Kelompok Usaha Kecil dan Mikro (UKM) sebagai motor penggerak ekonomi telah mendapatkan legitimasi dari UU No.9 Tahun 1995, namun kelompok UKM di wilayah Cikarang Bekasi dalam perkembangannya seringkali dihadapkan oleh berbagai dilema. Persoalan kecilnya akses permodalan dan sulitnya mendapat pembiayaan dari perbankan merupakan dilema yang sangat krusial bagi kelanjutan usaha UKM. Dapat dilihat dari seluruh total UKM tahun 2012 baru 45-55 persen UKM yang mendapatkan akses ke perbankan.

Hal ini karena umumnya masyarakat menengah ke bawah tidak memahami mekanisme yang diterapkan pada bank maupun lembaga keuangan formal, dan kurangnya perhatian dari pemerintah. Ditambah lagi, perbankan sebagai salah satu lembaga keuangan yang berfungsi sebagai pemberi pinjaman kepada pihak yang membutuhkan dana, memberikan dana dengan memberikan kriteria dan persyaratan yang cukup rumit bagi calon debiturnya, seperti: harus adanya jaminan, laporan keuangan, slip gaji,dan sebagainya. Sedangkan tidak semua masyarakat yang berprofesi sebagai pedagang kecil dan menengah mempunyai persyaratan-persyaratan yang diajukan oleh perbankan tersebut.

Terdapat dua masalah yang harus dijawab dalam penelitian ini dan setelah kedua pertanyaan masalah ini terjawab, maka penulis akan menganalisisnya lebih mendalam sebagai evaluasi untuk menemukan solusi dan memunculkan kebijakan yang memperkuat pengembangan usaha mikro dan kecil dalam mendapatkan akses pembiayaan di lembaga perbankan. Berikut adalah dua masalah dalam penelitian ini: (1) Apakah faktor-faktor yang mempengaruhi preferensi UKM di Pasar Baru Cikarang dalam memilih akses pembiayaan?; (2) Akses pembiayaan apa yang paling diminati atau yang paling banyak digunakan oleh pelaku UKM di Pasar Baru Cikarang? 


\section{TINJAUAN PUSTAKA}

Menurut Kotler (2000), preferensi digambarkan sebagai sikap konsumen terhadap produk dan jasa sebagai evaluasi dari sifat kognitif seseorang, perasaan emosional dan kecenderungan bertindak melalui objek atau ide. Sementara Schiffman dan Kanuk (2008) menyatakan sikap adalah ekspresi perasaan (inner feeling) yang mencerminkan apakah seseorang senang atau tidak senang, suka atau tidak suka, dan setuju atau tidak setuju terhadap suatu objek. Dalam psikolog, preferensi bisa dipahami sebagai sikap individu terhadap suatu objek, biasanya tercermin dalam proses pengambilan keputusan eksplisit (Lichtenstein dan Slovic, 2006). Preferensi terhadap lembaga pembiayaan adalah keinginan atau kecenderungan seseorang untuk memilih atau tidak memilih bertransaksi di lembaga pembiayaan baik formal maupun nonformal. Preferensi masyarakat dalam memilih akses pembiayaan sangat bervariasi, karena setiap individu mempunyai keinginan yang berbeda-beda dalam pilihannya.

\section{METODE}

Pada penelitian ini merupakan penelitian deskriptif dengan pendekatan kuantitatif yang menggunakan data satu waktu (cross-sectional). Teknis analisis data yang digunakan untuk penelitian ini yaitu dengan analisis deskriptif dan untuk menentukan dan menganalisis faktor-faktor yang mempengaruhi preferensi terhadap pilihan akses pembiayaan adalah dengan metode analisis Logistic Regression Model (LRM).

Metode pengumpulan data pengambilan sampel pada penelitian ini dilakukan secara purposive sampling, dimana pengambilan sampel didasarkan atas ciri-ciri atau sifat- sifat tertentu yang dipandang mempunyai kaitan erat dengan ciri atau sifat populasi yang sudah diketahui sebelumnya (Hadi: 2004). Adapun ciri-ciri tertentunya adalah hanya pada responden (pedagang) yang padat modal yang telah memilih akses pembiayaan baik di perorangan maupun lembaga konvensional atau syariah. Sehingga objek penelitian ini adalah para pedagang pasar yang berlokasi di Pasar Baru Cikarang yang beralamatkan di Jln.RE Martadinata No.02, Desa Cikarang Kota Kecamatan Cikarang Utara, Kabupaten Bekasi.

Instrumen dalam penelitian ini menggunakan kuesioner. Kuesioner disusun secara semi terstruktur dengan pertanyaan-pertanyaan yang telah disediakan pilihan jawabannya, sehingga responden tinggal memilih salah satu jawaban yang telah disediakan. Sebelum kuesioner disebarkan kepada responden, terlebih dahulu dilakukan pengujian validitas dan reliabilitas instrumen.

Untuk mengetahui apakah setiap butir pertanyaan pada setiap variabel dinilai valid atau tidak maka harus dilakukan cara-cara berikut ini (Rochaety, dkk, 2007): membandingkan $r$ tabel dengan setiap $r$ butir pertanyaan, dengan cara membandingkan output Correlated Item Total Correlation dengan nilai $r$ tabel. Sedangkan suatu konstruk dikatakan reliabel jika memberikan nilai Cronbach Alpha > 0.7 (Wijaya, 2009).

Distribusi normal merupakan distribusi kontinu yang sangat penting dalam statistika dan banyak dipakai dalam memecahkan persoalan (Gujarati, 2006). Distribusi normal disebut juga distribusi Gauss (Boediono dan Koster, 2008). Uji normalitas dilakukan untuk melihat apakah dalam model regresi variabel terikat dan variabel bebas keduanya mempunyai distribusi normal atau 
tidak. Dalam penelitian ini, uji normalitas data dilakukan dengan uji One-Sampel Kolmogorov-Sminorv Test.

Analisis regresi logistik dengan model logit adalah model regresi yang digunakan untuk melihat pengaruh sejumlah variabel independen $\mathrm{X}_{1}, \mathrm{X}_{2}, \mathrm{X}_{3}, \ldots \ldots, \mathrm{X}_{\mathrm{k}}$ terhadap variabel dependen $\mathrm{Y}$ yang berupa variabel kategorik (binominal, multinominal atau ordinal) dengan nilai kemungkinan diantara 0 dan 1 (Winarno, 2011). SPSS menyediakan tiga prosedur regresi logistik,yaitu: Regresi Logistik Biner (Binary Logistic Regression), Regresi Logistik Multinominal (Multinominal Logistic Regression), dan Regresi Logistik Ordinal (Ordinal Logistic Regression).

Regresi logistik biner sangat tepat digunakan untuk melakukan permodelan suatu kemungkinan kejadian dengan variabel respon bertipe kategori dua pilihan. Nilai kemungkinan kejadian berada pada rentang 0-1. Hal ini sangat berbeda dengan regresi linear biasa dimana nilai variabel dependen (variabel respon) bisa bernilai $<0$ atau $>$ dari 1 (Trihendardi, 2007). Model Binary Logistik dengan metode logit pada penelitian ini adalah sebagai berikut (Nachrowi dan Usman, 2008):

$$
L_{i}=\ln \left(\frac{P_{i}}{1-P}\right)=\beta_{0}+\beta_{1} X_{i}+\mu_{i}
$$

$\operatorname{Prf}=\beta_{0}+\beta_{1} \mathrm{LAY}+\beta_{2}$ PROD $+\beta_{3} \mathrm{AGAMA}_{1}+\beta_{4} \mathrm{AGAMA}_{2}+\beta_{5} \mathrm{DIDIK}_{1}+$

$\beta_{6}$ DIDIK $_{2}+\beta_{7}$ DIDIK $_{3}+\beta_{8}$ DIDIK $_{4}+\mu_{\mathrm{i}}$

Dimana:

Li sebagai preferensi UKM dalam memilih akses pembiayaan.

Dimana: $L_{i}=0$, berarti Lembaga Keuangan Konvensional

$\mathrm{Li}=1$, berarti Lembaga Keuangan Syariah

$\beta_{0}$ sebagai konstanta

$\beta_{\mathrm{i}}$ sebagai koefisien regresi dari masing-masing variabel independen

$\mathrm{X}_{\mathrm{i}}$ sebagai variabel bebas, dimana

LAY = Layanan

PROD = Produk

$\mathrm{AGAMA}_{1}, \mathrm{AGAMA}_{2}, \mathrm{DIDIK}_{1}, \mathrm{DIDIK}_{2}, \mathrm{DIDIK}_{3}, \mathrm{DIDIK}_{4}$ sebagai variabel kontrol

\section{PEMBAHASAN}

Pada penelitian ini, diketahui 37 persen responden pernah mengakses pembiayaan di lembaga keuangan syariah dan 63 persen responden pernah mengakses pembiayaan di lembaga keuangan konvensional. Dari data yang telah didapat rata-rata usia responden yang mengakses pembiayaan adalah 24-65 tahun. Terkait dengan agama yang dianut oleh responden yang memilih akses pembiayaan di lembaga keuangan syariah. Dari 37 responden, terdapat 97,3\% responden yang menganut/memeluk agama Islam dan 2,7\% responden yang menganut agama Kristen. Dapat disimpulkan bahwa responden yang beragama Islam lebih banyak memilih akses pembiayaan syariah.

Berdasarkan responden yang ada, terdapat 5,4\% yang pendidikan terakhirnya $\mathrm{SD} /$ sederajat, $8,1 \%$ responden yang pendidikan terakhirnya SMP/sederajat, 83,3\% responden yang pendidikan terakhirnya SMA/sederajat dan 2,7\% responden yang pendidikan terakhirnya Diploma/sederajat. Dapat disimpulkan bahwa responden yang pendidikan terakhir SMA/sederajat lebih 
banyak memilih akses pembiayaan syariah. Jenis usaha/dagangan yang dijual oleh responden yang memilih akses pembiayaan di lembaga keuangan syariah. Terdapat $27 \%$ adalah usaha sembako, $13,5 \%$ adalah usaha pakaian, $16,2 \%$ adalah usaha kelontong, 8,1\% adalah usaha peralatan rumah tangga dan $35,1 \%$ usaha lainnya.

Berdasarkan sebaran kuesioner yang dilakukan, terdapat 16,2\% yang memilih Bank Syariah, 24,3\% memilih Koperasi Syariah, 37,8\% memilih BMT, 13,5\% memilih BPRS, dan 8,1\% memilih Pegadaian Syariah. Dilihat dari jenis pembiayaan yang diambil terdapat 33 orang mengambil jenis pembiayaan Mudharabah dan Murabahah, 1 orang mengambil jenis pembiayaan musyarakah dan 3 orang mengambil jenis pembiayaan Rahn dan Qardh. Dapat disimpulkan bahwa responden lebih banyak memilih akses pembiayaan kepada BMT.

Dalam menentukan uji validitas dan reliabilitas instrument, peneliti menggunakan dengan cara menentukan besarnyar tabel dengan ketentuan tingkat kepercayaan (degree of freedom= df) jumlah kasus dikurangi dua, membandingkan $\mathrm{r}$ tabel dengan cara membandingkan output Correlated Item Total Correlation dengan nilai $r$ tabel. Dari rumus tersebut, nilai $r$ tabel untuk penelitian ini yaitu $100-2=98$, tingkat signifikan $5 \%$, maka nilai $r$ tabel sebesar 0,196 dan dinyatakan valid karena $r$ hitung lebih besar dari $r$ tabel. Dan hasil uji reliabilitas pada pertanyaan kuesioner diperoleh hasil alpha hitung 0,762 , maka kuesioner terbukti handal atau reliabel karena Cronbach alpha $>0,7$.

Uji normalitas dilakukan untuk mengetahui kecocokan metode logit atau probit yang digunakan untuk penelitian ini, maka perlu melakukan uji normalitas. Untuk uji normalitas peneliti menggunakan One Sample KolmogorovSminorv Test dengan melihat tingkat signifikansi 5\% pada masing-masing variabel. Jika variabel tidak berdistribusi normal maka metode logit yang dipakai, namun jika variabel berdistribusi normal, maka metode probit yang dipakai.

Dari hasil pengujian normalitas data dapat diketahui bahwa variabel bebas $\mathrm{X}_{1}, \mathrm{X}_{3}, \mathrm{X}_{4}, \mathrm{X}_{5}, \mathrm{X}_{6}, \mathrm{X}_{7}$ dan $\mathrm{X}_{8}$ mempunyai distribusi tidak normal sehingga model yang dipakai adalah model logit. Dan untuk variabel bebas $X_{2}$ mempunyai distribusi normal sehingga model yang dipakai adalah probit. Meskipun berbeda kedua model logit dan probit memiliki jenis metode yang sama. Tidak ada alasan yang memaksa untuk harus menggunakan metode yang satu dibandingkan lainnya. Dalam penelitian ini penulis menggunakan metode logit.

Analisis regresi logistik Binary dengan model logit adalah model regresi yang digunakan untuk melihat pengaruh sejumlah variabel independen $X_{1}, X_{2}$, $\mathrm{X}_{3} \ldots \ldots, \mathrm{X}_{\mathrm{k}}$ terhadap variabel dependen $\mathrm{Y}$ yang dengan nilai kemungkinan diantara 0 dan 1. Dalam penelitian ini jumlah data yang diproses sebanyak 100 atau N 100, untuk melihat kelengkapan data yang diproses dalam penelitian ini dan tidak ada missing case, artinya data yang diproses lengkap.

Uji wald ratio adalah untuk mengetahui pengaruh masing-masing variabel independen terhadap variabel dependen. Untuk uji hipotesis masing-masing variabel sebagai berikut:

$\mathrm{H}_{0}: \beta_{1}, \beta_{2}, \ldots \beta_{\mathrm{k}}=0$, yang berarti tidak ada pengaruh yang signifikan antara variabel independen $(\mathrm{X})$ terhadap variabel dependen $(\mathrm{Y})$.

$\mathrm{H}_{1}: \beta_{1}, \beta_{2}, \ldots \beta_{\mathrm{k}} \neq 0$, yang berarti terdapat pengaruh yang signifikan antara variabel independen $(\mathrm{X})$ terhadap variabel dependen $(\mathrm{Y})$. 
Dengan demikian, langkah-langkah pengujiannya adalah sebagai berikut: Jika nilai probabilitas $>0,05$, maka $\mathrm{H}_{0}$ diterima Jika nilai probabilitas $<0,05$ maka $\mathrm{H}_{0}$ ditolak.

Uji Wald menguji masing-masing koefisien regresi logistik, sebagai berikut:

1. Uji koefisien variabel $\mathrm{X}_{1}$ (LAY): Uji Wald $=2,360, P$-Value $=0,124>\alpha=0,05$, maka koefisien regresi untuk variabel $\mathrm{X}_{1}(\mathrm{LAY})$ tidak signifikan.

2. Uji koefisien variabel $\mathrm{X}_{2}$ (PROD): Uji Wald $=16,162$, $P$-Value $=0,000<\alpha=$ 0,05 , maka koefisien regresi untuk variabel $X_{2}$ (PROD) signifikan.

3. Untuk koefisien variabel $\mathrm{X}_{3}\left(\mathrm{AGAMA}_{1}\right)$ : UjiWald $=0,000, P$-Value $=0,986$ $>\alpha=0,05$, maka koefisien regresi untuk variabel $\mathrm{X}_{3}\left(\mathrm{AGAMA}_{1}\right)$ tidak signifikan.

4. Untuk koefisien variabel $\mathrm{X}_{4}\left(\mathrm{AGAMA}_{2}\right)$ : $\mathrm{UjiWald}=0,000, P$-Value $=0,987>\alpha$ $=0,05$, maka koefisien regresi untuk variabel $\mathrm{X}_{4}$ (AGAMA2) tidak signifikan.

5. Uji koefisien variabel $\mathrm{X}_{5}\left(\right.$ DIDIK $\left._{1}\right)$ : Uji Wald $=0,245, P$-Value $=0,620>\alpha=$ 0,05 , maka koefisien regresi untuk variabel $X_{5}$ (DIDIK1)tidak signifikan.

6. Uji koefisien variabel $\mathrm{X}_{6}\left(\right.$ DIDIK $\left._{2}\right)$ : Uji Wald $=0,280, P$-Value $=0,597>\alpha=$ 0,05 , maka koefisien regresi untuk variabel $\mathrm{X}_{6}\left(\mathrm{DIDIK}_{2}\right)$ tidak signifikan.

7. Uji koefisien variabel $\mathrm{X}_{7}$ (DIDIK $)$ ): Uji Wald $=0,018, P$-Value $=0,894>\alpha=$ 0,05 , maka koefisien regresi untuk variabel $\mathrm{X}_{7}\left(\mathrm{DIDIK}_{3}\right)$ tidak signifikan.

8. Uji koefisien variabel $\mathrm{X}_{8}$ (DIDIK 4 ): Uji Wald $=0,000, P$-Value $=0,987>\alpha=$ 0,05 , maka koefisien regresi untuk variabel $\mathrm{X}_{8}\left(\mathrm{DIDIK}_{4}\right)$ tidak signifikan.

Dengan demikian, berdasarkan hasil perhitungan koefisien dari model regersi logistik yang terlihat menunjukkan bahwa variabel $X_{1}$ (LAY), $X_{3}$ $\left(\right.$ AGAMA $\left._{1}\right), \mathrm{X}_{4}\left(\mathrm{AGAMA}_{2}\right), \mathrm{X}_{5}\left(\right.$ DIDIK $\left._{1}\right), \mathrm{X}_{6}\left(\right.$ DIDIK$\left._{2}\right), \mathrm{X}_{7}\left(\mathrm{DIDIK}_{3}\right), \mathrm{X}_{8}\left(\mathrm{DIDIK}_{4}\right)$, tidak mempunyai pengaruh signifikan terhadap variabel Y. Sedangkan untuk variabel $\mathrm{X}_{2}$ (PROD) mempunyai pengaruh yang signifikan terhadap preferensi dalam memilih akses pembiayaan di lembaga keuangan syariah dan konvensional dengan koefisien variabel $\mathrm{X}_{2}$ (PROD) signifikan pada probabilitas $0,000<\alpha=0,05$, maka dapat disimpulkan bahwa terdapat perbedaan antara produk layanan lembaga keuangan syariah dengan lembaga keuangan konvensional.

Berdasarkan dari empat faktor yang dianalisis sebagai faktor yang mempengaruhi preferensi dalam memilih akses pembiayaan, hanya ada satu faktor yang berpengaruh signifikan terhadap preferensi dalam memilih akses pembiayaan, yaitu: faktor produk yang terdiri dari:

1. Bunga/Margin/Bagi Hasil yang rendah.

2. Produk yang beragam.

3. Plafond yang sesuai dengan kebutuhan.

4. Terdapatnya bimbingan untuk pengembangan usaha.

Hal tersebut didapat dari hasil perhitungan uji Wald Statistik yang menunjukkan bahwa hanya ada satu variabel yang berpengaruh signifikan terhadap variabel dependen yaitu variabel Produk dengan koefisien variabel $\mathrm{X}_{2}$ (PROD) signifikan pada probabilitas $0,000<\alpha=0,05$, sedangkan variabel yang lainnya tidak berpengaruh.

Persamaan regresi yang dibentuk adalah sebagai berikut:

Pref $=-30,680+1,398$ PROD 
Dari persamaan regresi logistik di atas, dapat dilihat bahwa variabel LAY, AGAMA $_{1}$, AGAMA $_{2}$, DIDIK$_{1}$, DIDIK$_{2}$, DIDIK$_{3}$, dan DIDIK 4 tidak mempunyai pengaruh yang signifikan terhadap preferensi UKM di Pasar Baru Cikarang dalam memilih akses pembiayaan. Koefisien regresi PROD sebesar 1,398 dan bernilai positif menunjukkan bahwa variabel PROD berpengaruh positif terhadap preferensi UKM dalam memilih akses pembiayaan baik di lembaga keuangan syariah maupun konvensional, artinya jika variabel lain dianggap konstan, maka setiap unit perubahan variabel PROD kemungkinan preferensi UKM dalam memilih akses pembiayaan di lembaga keuangan konvensional adalah 4,049 kali lebih tinggi daripada preferensi UKM dalam memilih akses pembiayaan di lembaga keuangan syariah.

Dengan demikian, hasil penelitian ini didukung oleh teori Schiffman dan Kanuk (2008) yang menyatakan bahwa salah satu faktor-faktor yang mempengaruhi preferensi yaitu karena faktor produk yang ditimbulkan dari usaha pemasaran perusahaan. Berbeda dengan penelitian terdahulu yang dilakukan oleh Sirat Qidrotullah dan Ratih Komalarini Saidah dengan hasil penelitiannya, yang menyatakan bahwa faktor-faktor yang mempengaruhi preferensi pedagang dalam memilih akses pembiayaan dikarenakan faktor pelayanaan (pelayanan yang ramah, kemudahan dalam persyaratan, tidak adanya jaminan, dan dana yang cepat), faktor kepercayaan dan faktor kekerabatan.

Berdasarkan hasil analisis data penelitian secara deskriptif, diketahui bahwa dari 100 responden terdapat 37\% yang pernah memilih akses pembiayaan di Lembaga Keuangan Syariah dan 63\% yang pernah memilih akses pembiayaan di Lembaga Keuangan Konvensional. Dapat disimpulkan bahwa Usaha Kecil Mikro (UKM) di Pasar Baru Cikarang lebih berminat atau cenderung memilih akses pembiayaan di Lembaga Keuangan Konvensional dan sumber pembiayaan yang paling banyak diakses oleh UKM/Pedagang adalah BPR (Bank Perkreditan Rakyat), bahkan mengakses kepada Bank Keliling (Renternir).

Hal tersebut dikarenakan beberapa sebab, yaitu: pertama, masyarakat lebih melihat keuntungan yang besar dengan cara yang mudah. Kedua, kurangnya pemahaman masyarakat awam tentang keharaman riba atau lebih dikenal dengan bunga yang sudah sangat jelas keharamannya didalam Al-Qur'an dan AsSunnah, serta ada pula yang memahami namun mereka tetap bertransaksi dengan sistem riba itu, karena mereka tidak ada rasa takut kepada Allah Swt. Ketiga, kurangnya tawakkal kepada Allah Swt. Sehingga mereka menganggap rezeki itu terbatas dan sempit dan jika tidak ada pintu rezekiyang halal kemudian mereka akan bertransaksi dengan bank-bank ribawi, dan banyak responden yang beranggapan bahwa Lembaga Keuangan Syariah masih belum banyak di daerah Cikarang sehingga sulit untuk dijangkau dan sebagian besar para UKM beranggapan bahwa Lembaga Keuangan Syariah tidak ada bedanya dengan Lembaga Keuangan Konvensional karena penetapan margin di pembiayaan syariah sama halnya seperti bunga di pembiayaan konvensional yang hanya membedakan dalam penyebutannya saja. Dengan demikian, berdasarkan dari beberapa sebab yang telah disebutkan diatas menunjukkan bahwa masih banyak masyarakat khususnya pedagang yang masih belum mengetahui atau memahami tentang keharaman riba dan akibat yang akan didapatkannya, sehingga mereka lebih memilih untuk bertransaksi dengan bank-bank ribawi dibandingkan 
memilih bertransaksi di lembaga keuangan syariah.

\section{SIMPULAN}

Dari hasil penelitian ini terdapat dua kesimpulan, pertama menunjukkan bahwa hanya ada satu faktor yang berpengaruh signifikan terhadap preferensi Usaha Kecil Mikro (UKM) di Pasar Baru Cikarang dalam memilih akses pembiayaan yaitu Faktor Produk yang meliputi: bunga/margin/bagihasil yang rendah, produk yang beragam, plafond yang sesuai dengan kebutuhan, dan terdapatnya bimbingan untuk pengembangan usaha. Hal tersebut dilihat dari hasil Uji Wald pada Regresi Logistik yang menunjukan bahwa hanya ada satu variabel yang berpengaruh signifikan terhadap variabel dependen yaitu variabel Produk dengan koefisien variabel $\mathrm{X}_{2}$ (PROD) signifikan pada probabilitas $0,000<\alpha=0,05$. Kedua, menunjukkan bahwa dari 100 responden, terdapat 37\% yang pernah memilih akses pembiayaan di Lembaga Keuangan Syariah dan 63\% yang pernah memilih akses pembiayaan di Lembaga Keuangan Konvensional. Dari hasil tersebut, dapat disimpulkan bahwa Usaha Kecil Mikro (UKM) di Pasar Baru Cikarang lebih berminat atau cenderung memilih akses pembiayaan di Lembaga Keuangan Konvensional.

Berdasarkan persamaan regresi logistik di atas, dapat dilihat bahwa variabel LAY, AGAMA 1, AGAMA $_{2}$, DIDIK$_{1}$, DIDIK$_{2}$, DIDIK$_{3}$, dan DIDIK 4 tidak mempunyai pengaruh yang signifikan terhadap preferensi UKM di Pasar Baru Cikarang dalam memilih akses pembiayaan. Koefisien regresi PROD sebesar 1,398 dan bernilai positif menunjukkan bahwa variabel PROD berpengaruh positif terhadap preferensi UKM dalam memilih akses pembiayaan baik di lembaga keuangan syariah maupun konvensional, artinya jika variabel lain dianggap konstan, maka setiap unit perubahan variabel PROD kemungkinan preferensi UKM dalam memilih akses pembiayaan di lembaga keuangan konvensional adalah 4,049 kali lebih tinggi daripada preferensi UKM dalam memilih akses pembiayaan di lembaga keuangan syariah

\section{PUSTAKA ACUAN}

Al Arif, M. N. R. 2011. Dasar-dasar Ekonomi Islam. Surakarta: Era Intermedia.

Amalia, Euis. 2009. Keadilan Distributif dalam Ekonomi Islam Penguatan Peran LKM dan UKM di Indonesia. Jakarta: Rajawali Pers.

Boediono dan Wayan Koster. 2008. Teori dan Aplikasi Statistika dan Probabilitas. Bandung: PT Remaja Rosdakarya.

Gujarati, D. N. 2006. Dasar-dasar Ekonometrika. Ed.Ketiga, Jilid1. Jakarta: Erlangga. Hadi, Sutrisno. 2004. Metodologi Research. Jilid 1, Ed.Kedua.Yogyakarta: Andi Offset Husnayain, Ihdal. 2007. "Analisis Ekonomi Kejahatan Properti di Indonesia Tahun 2005."Skripsi S1 Fakultas Ekonomi, Universitas Indonesia

Kotler, Philip. 2000. Manajemen Pemasaran. Jakarta: Prehalindo

Lichtenstein, S dan P. Slovic. 2006. The Construction of Preference. New York: Cambridge University Press.

Nachrowi, N. D. dan H. Usman. 2008. Penggunaan Teknik Ekonometri: Pendekatan Populer dan Praktis Dilengkapi Teknik Analisis dan Pengolahan Data dengan Menggunakan Paket Program SPSS. Jakarta: PT RajaGrafindo Persada.

Rochaety, Ety, dkk. 2007. Metode Penelitian Bisnis: Dengan Aplikasi SPSS. 
Jakarta: Mitra Wacana Media, 2007.

Schiffman, Leon dan Leslie Lazar Kanuk. 2008. Prilaku Konsumen, Ed. Ke-7. Jakarta: PT INDEKS

Shobah, M. N. 2009. "Analisis Rasio CAMEL Dengan Metode Regresi Logistik Pada Bank Devisa dan Bank Non Devisa". Skripsi S1 Fakultas Ilmu Ekonomi dan Sosial, Universitas Islam Negeri Syarif Hidayatullah Jakarta.

Trihendradi, C. 2007. Kupas Tuntas Analisis Regresi. Yogyakarta: Penerbit Andi.

Winarno,W.W. 2011. Analisis Ekonometrika dan Statistika dengan Eviews Ed. Ketiga. Yogyakarta: Unit Penerbit dan Percetakan STIM YKPN

Wijaya, Tony. 2009. Analisis Data Menggunakan SPSS. Yogyakarta: Universitas AtmaJaya Yogyakarta 